\title{
Food security and migration in Africa: a validation of theoretical links using case studies from literature
}

\author{
luca Mulazzani*, Rosa Manrique*, Catalina Stancu*, Giulio Malorgio*
}

DOI: $10.30682 / \mathrm{nm} 2002 \mathrm{~b}$

JEL codes: F22, F24, Q54, R23

\begin{abstract}
The connection between food security and migration is increasingly discussed by both international agencies and academic literature. However, despite several improvements, we continue to know little about the complex causal-effect relations that link these aspects and, in particular, how much migration patterns are affected by food security issues and how much, as a feedback, migration can affect food security, on both the origin and destination areas. This paper aims firstly to draw a general framework of this nexus and then to validate it using empirical literature on the African continent. A few common points can be emphasized for the continent: due to structural and familiar characteristics, different strategies based on opportunity costs or risk minimization (including food security aspects) may emerge; individuals often migrate following household strategies; multi-nodal households are emerging; land grabbing and land tenure security represent important drivers to be considered; emergencies or critical situations often cause the erosion of women rights. In many situations, the poverty trap prevents most food insecure households to leave marginal lands.
\end{abstract}

Keywords: Migration, Food insecurity, Climate change, Africa, Remittances.

\section{Introduction}

Food security ${ }^{1}$ and migration are interrelated themes. Their connection is increasingly discussed by both international agencies and academic literature. The Food and Agriculture Organization (FAO) has recently highlighted that agriculture and rural development are key to addressing the root causes of migration (FAO, 2016). For this reason, the world food day organized by FAO in 2017 was focused on the future of migration, investment in food securi- ty and rural development. At the same time, the United Nations Refugee Agency (UNHCR) recognizes the importance to ensure access to adequate nutrient-rich food of millions who have been forced to flee (UNHCR, n.d.).

Several special issues that prestigious academic journals have dedicated to food security and migration links prove the growing interest of the scientific community. Three monographic numbers of great interest can be highlighted: one dedicated by Social Research to "Food

\footnotetext{
* University of Bologna, Italy.

Corresponding author: luca.mulazzani@unibo.it
}

\footnotetext{
1 The standard definition of food security was developed at the 1996 World Food Summit namely that "food security exists when all people, all the times, have physical and economic access to sufficient, safe and nutritious food that meets their dietary needs and food preferences for an active and healthy life".
} 
scarcity and migration" (Fukuda-Parr, 2014), one by Food Policy to "Migration and nutrition" (Zezza et al., 2011), and one by International Migration to "Migration and food security" (Crush and Caesar, 2017). While the Social Research issue deals with food security as a cause of migration, the other two monographies focus mainly on the consequences of migration, considering the role of remittances, the reduction of agricultural labour force, and the food security of migrants at their destination and of families in their native areas.

A few international projects have analysed numerous case studies around the world to find common patterns between food and migration, in particular under the framework of climate change. Three projects deserve special attention: a) "In search of shelter: mapping the effects of climate change on human migration and displacement" carried out by CARE International, Columbia University, UNHCR, United Nations University Institute for Environment and Human Security, and the World Bank (Koko Warner et al., 2009); b) "Migration and global environmental change: future challenges and opportunities" carried out by The Government Office for Science (Foresight, 2011); c) "EACH-FOR: Environmental Change and Forced Migration Scenarios" carried out by a consortium of European institutions (Jäger et al., 2009). However, beyond these large international projects, scientific literature counts with very few comparative studies carried out on more than one country. An example is Findlay (2011) that uses data from the US AID's Famine Early Warning System Network to realize a review of migrant destination choices.

Some broad conclusions can be drawn through these studies, which largely agree on two essential aspects. Firstly, climate (and environmental) change is only one of many contributing factors of migration; traditional migration patterns have also changed due to rapidly changing socio-economic and political conditions. Secondly, socio-economic system characteristics play a mediating role in how environmental change affects migration decisions. Studies in a wide range of countries have shown that migration is positively associated with wealth and social capital. Those with lower wealth or capital (which are also more vulnerable to environmental change) are unable to move away from situations of increasing threats (i.e. "trapped population").

Despite these advances, the nexus between migration and food security remains a peripheral and much neglected concern according to Crush and Caesar (2017), while we continue to know little about the socio-economic outcomes in terms of migration due to changes and stresses on ecological systems (Warner et al., 2010).

This paper aims to highlight the main aspects of this nexus using empirical literature on the African continent to verify which of the several links introduced by theoretical literature have been analysed in practice, and which are the results obtained. In order to accomplish this general objective, a three steps procedure is followed: a) firstly, statistical data on African countries are provided to evaluate if there exists some clear causal-effect relation between food security and migration; b) then, a general theoretical framework of the relationship between food security and migration is presented, building on existing literature; c) finally, African empirical case studies from scientific literature are illustrated and discussed to highlight the findings related to the framework previously presented. Probably, this paper will not solve the concerns introduced by Crush and Caesar (2017) and Warner et al. (2010), but it could stress which patterns are more common in the nexus between migration and food security in African countries, and which elements have been underrated until now.

\section{An overview of African countries}

Migration in Africa involves roughly equal numbers of international migrants moving either within or out of the continent (figures are increasing in both directions). According to the International Organization of Migration (IOM, 2011), in 2015 over 16 million Africans were living in another African country, while an additional 16 million were living in a different continent. At the same time, since 2010, food security situation has visibly worsened in many parts of Africa, where more than 243 million people are undernourished (FAO et al., 2017). 
Table 1 - GDP per capita, food supply and proportion of migrant population of African countries (not all countries are included due to lack of data) ordered by food supply. GDP per capita is calculated as PPP (constant 2011 international \$) in 2017 (source: World Bank, 2018); food supply per capita is calculated as kcal/day in 2013 (source: FAO, 2017); proportion of migrant population is calculated as the ratio between migrant stock by origin in 2017 (source: United Nations, 2017) and total population of the origin country (source: World Bank, 2018).

\begin{tabular}{|c|c|c|c|c|c|c|c|}
\hline Country & $\begin{array}{c}\text { GDP per } \\
\text { capita, PPP }\end{array}$ & $\begin{array}{c}\text { Food supply } \\
\text { (kcal/capita/ } \\
\text { day) }\end{array}$ & $\begin{array}{l}\text { Migrant } \\
\text { stock/ } \\
\text { Popul. }\end{array}$ & Country & $\begin{array}{c}\text { GDP per } \\
\text { capita, PPP }\end{array}$ & $\begin{array}{c}\text { Food supply } \\
\text { (kcal/capita/ } \\
\text { day) }\end{array}$ & $\begin{array}{c}\text { Migrant } \\
\text { stock/ } \\
\text { Popul. }\end{array}$ \\
\hline Egypt & 10551 & 3522 & $3,6 \%$ & Malawi & 1095 & 2367 & $1,9 \%$ \\
\hline Morocco & 7476 & 3403 & $8,2 \%$ & Sudan & 4467 & 2336 & $4,9 \%$ \\
\hline Tunisia & 10849 & 3349 & $6,7 \%$ & Swaziland & & 2329 & $6,8 \%$ \\
\hline Algeria & 13900 & 3296 & $4,4 \%$ & Botswana & 15473 & 2326 & $3,6 \%$ \\
\hline Mauritius & 20320 & 3065 & $13,2 \%$ & Guinea-Bissau & 1549 & 2292 & $5,4 \%$ \\
\hline South Africa & 12294 & 3022 & $1,6 \%$ & Mozambique & 1136 & 2283 & $3,3 \%$ \\
\hline Ghana & 4092 & 3016 & $3,0 \%$ & Rwanda & 1857 & 2228 & $4,8 \%$ \\
\hline Mali & 2016 & 2890 & $5,9 \%$ & Congo, Rep. & 4958 & 2208 & $5,0 \%$ \\
\hline Mauritania & 3598 & 2876 & $2,8 \%$ & $\begin{array}{l}\text { United Republic } \\
\text { of Tanzania }\end{array}$ & 2679 & 2208 & $0,6 \%$ \\
\hline Gabon & 16464 & 2830 & $3,4 \%$ & Kenya & 2993 & 2206 & $1,0 \%$ \\
\hline Côte d'Ivoire & 3586 & 2799 & $3,5 \%$ & Liberia & 1168 & 2204 & $5,6 \%$ \\
\hline Burkina Faso & 1696 & 2720 & $7,9 \%$ & Namibia & 9517 & 2171 & $7,7 \%$ \\
\hline Nigeria & 5351 & 2700 & $0,7 \%$ & Ethiopia & 1730 & 2131 & $0,8 \%$ \\
\hline Cameroon & 3383 & 2671 & $1,4 \%$ & Uganda & 1698 & 2130 & $1,8 \%$ \\
\hline Gambia & 1544 & 2628 & $4,3 \%$ & Chad & 1768 & 2110 & $1,7 \%$ \\
\hline Benin & 2069 & 2619 & $5,8 \%$ & Zimbabwe & 2212 & 2110 & $4,5 \%$ \\
\hline Cabo Verde & 6283 & 2609 & $42,0 \%$ & Madagascar & 1416 & 2052 & $0,7 \%$ \\
\hline Djibouti & & 2607 & $1,7 \%$ & Zambia & 3665 & 1930 & $1,7 \%$ \\
\hline Guinea & 2042 & 2566 & $3,4 \%$ & $\begin{array}{l}\text { Central African } \\
\text { Republic }\end{array}$ & 661 & 1879 & $15,8 \%$ \\
\hline Niger & 926 & 2547 & $1,8 \%$ & Burundi & 668 & & $4,1 \%$ \\
\hline Lesotho & 2665 & 2529 & $14,8 \%$ & $\begin{array}{l}\text { Congo, Dem. } \\
\text { Rep. }\end{array}$ & 808 & & $2,1 \%$ \\
\hline Angola & 6052 & 2473 & $2,2 \%$ & $\begin{array}{l}\text { Equatorial } \\
\text { Guinea }\end{array}$ & 22213 & & $7,8 \%$ \\
\hline Senegal & 3143 & 2456 & $3,6 \%$ & Libya & & & $2,5 \%$ \\
\hline Togo & 1512 & 2454 & $6,0 \%$ & Seychelles & 26657 & & $38,4 \%$ \\
\hline Sierra Leone & 1391 & 2404 & $2,1 \%$ & Somalia & & & $13,9 \%$ \\
\hline $\begin{array}{l}\text { Sao Tome and } \\
\text { Principe }\end{array}$ & 3053 & 2400 & $41,2 \%$ & South Sudan & & & $14,3 \%$ \\
\hline
\end{tabular}

We collected data on food security and migration at national level from international institutions to verify if simple, linear relationships between these concepts do exist for the African countries. As an index of food security, we considered the food supply measured by FAO as $\mathrm{kcal} /$ capita/day (FAO, 2017); on the other side, we considered the ratio of migrant population for every country, calculated using existing data on migrant stocks (United Nations, 2017) (i.e. migrant stock by origin / population of the origin country). These figures, as well as data on gross domestic product (GDP) per capita, are shown in Table 1 and plotted together in Figure 1.

At national level, data do not show any clear relationship between food security and migration patterns that can be considered valid for the entire continent (neither exists a clear relation- 


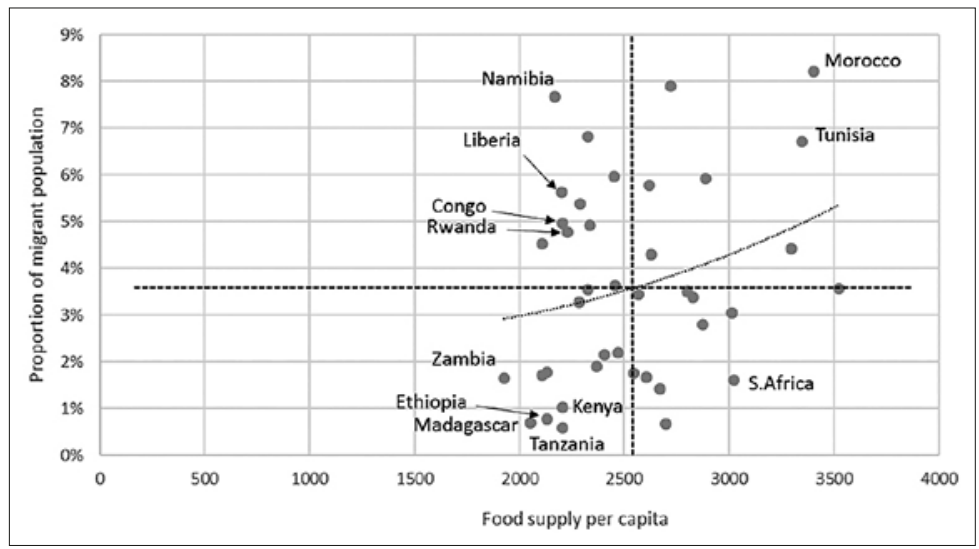

Figure 1 - Relationship between food security and migration patterns. Points indicate the level of food supply (kcal/capita/day) (FAO, 2017) and the proportion of migrant population (United Nations, 2017). The plot is divided into four quarters using the average values of the two indices. ship between GDP per capita and migration). On the other hand, it can be interesting to highlight the countries that present extreme combinations of food security and migration figures (Figure 1). Five countries (mainly small archipelagos) have been excluded from Figure 1 since they present exceptionally high $(>13 \%)$ ratios of migration (see Table 1); these are Cape Verde, Sao Tome and Principe, Central African Republic, Lesotho and Mauritius.

Figure 1 is useful to highlight some geographical patterns. In the upper right quarter of the plot, are shown countries presenting high levels of migration and high levels of food supply. Thus, these nations have relatively good standards of nutrition but population seeks for better conditions abroad: representative countries of this group are Tunisia and Morocco, which find good opportunities of migration due to their geographic and historic connections with Europe. In the opposite quarter (lower, left) we find countries as Zambia, Madagascar, Ethiopia, Kenya and Tanzania where migration ratios are very low. In this group, it is possible to select situations of poverty traps. However, lower levels of migration can also be considered the result of cultural and historic patterns that affect household preferences and decisions.

In the upper left quarter, are shown countries that mostly try to escape from low levels of food supply through migration. Here, we find Namibia (which is affected by the pull factors from South Africa) and countries such as Liberia, Congo and Rwanda, where climatic and economic factors merge with humanitarian crises and warfare to induce people to migrate. Finally, the lower right side is mainly represented by South Africa, a country with relatively high standards of food supply where population does not migrate because has not opportunities to find better conditions in neighbour countries.

\section{Definitions and general framework}

The 1996 World Food Summit stated the standard definition of food security (see note 1). On the other hand, human mobility is generally divided in migration, if driven by socio-economic factors (i.e. voluntary migration), and displacement, if caused by natural or human factors (i.e. forced displacement) (FAO, 2016). People forced to flee for reasons of race, religion, nationality or political opinion can be considered as refugee and asylum seekers. However, the term "environmental refugee" is controversial since the word "refugee" has a legal definition in the 1951 United Nations Convention Relating to the Status of Refugees and does not apply to those displaced by environmental changes. For this reason, most of authors prefer to use terms as "environmentally displaced persons" and "environmental migrants" (Jäger et al., 2009). If forced movements occur within home country's borders, the term "internally displaced persons" is used.

A general (and simplified) framework from the most relevant literature on the interlinkages between migration and food security is analysed (Figure 2). 
Food security is fostered by many factors, including economic growth, agricultural productivity, markets (international trade) and social protection. Among negative drivers, a special attention is given to climate change and conflicts (FAO et al., 2015; 2017). Economic growth increases household incomes and employment opportunities; however, distribution patterns of richness should be considered. Improved productivity of agricultural resources can be reached by sustainable intensification (e.g. sustainable land management, soil conservation, water management, diversified agricultural systems) or more conventional yield-enhancing technologies (e.g. improved seed varieties, mineral fertilizers). Constraining factors that compromise agricultural productivity gains include weather-related shocks, poor transport, storage and communications infrastructure, missing or inefficient markets, weak institutions and inadequate agricultural policies; greater uncertainty and higher risks reduce the incentives to invest in agricultural production (FAO et al., 2015). International trade and trade policies affect the domestic availability and prices of goods (Lacirignola et al., 2015). Trade policies have normally opposite effects on farmers and urban population, thus final results on food security are mixed. Finally, social protection (e.g. school-feeding programs, cash transfers) has a direct contribution to hunger reduction.

Besides climate change, conflicts represent a second important risk for food security and a driver of migration as well (FAO et al., 2017). Conflict impacts can be direct (e.g. forced population movements, the destruction of food stocks and productive assets) and indirect (e.g. reduction of employment and income opportunities, social networks and market disruption, inflation). However, if conflicts cause food insecurity, the reverse causal link can also apply creating a vicious circle, where food insecurity, food price hikes, and competition for natural resources create feelings of anger and unfairness (FAO et al., 2017).

Many theoretical models try to explain the causes and drivers of migration. In traditional migration models developed by Lewis and Todaro, "decisions are carried out by individu- als and shaped by known and expected income differences" while "migration represents a loss of human resources for migrant sending areas" (Taylor, 1999). In other words, decisions should be driven by a rationale based on opportunity costs (i.e. cost-benefit analysis) (Post et al., 2016). On the contrary, the new economics of labour migration (NELM) argues that migration decisions are part of family strategies (as a mechanism for diversifying risk and gaining access to capital) and remittances set in motion a development dynamic. Thus, motives for remitting include pure altruism, pure self-interest and mutually beneficial, informal contracts (i.e. risk handling) (Taylor, 1999). Furthermore, it is unrealistic to assume that people may enjoy full access information to maximize their utility (Carling and Collins, 2018).

For Black et al. (2011) migration has five drivers: economic, political, demographic, social and environmental. These drivers include both push and pull forces, where push forces relate to the source area while pull factors relate to the destination area (Warner et al., 2010). Access to family, social or other networks, both at home and at destination, facilitates migration. Education generally increases the ability and aspiration to migrate (Foresight, 2011). Destination is also shaped by pre-existing social and cultural connections (Findlay, 2011). However, migratory aspirations may shift due to knowledge and information exchanges between geographic places (Foresight, 2011).

When people are faced with severe environmental degradation, they have one of three options: stay and adapt to mitigate the effects; stay, do nothing and accept a lower quality of life; or leave the affected area. However, since both future environmental conditions and outcomes of human coping decisions are uncertain, and since consequences of wrong choices can result to be fatal, final decisions are generally aimed to minimize risk rather than maximize expected benefits.

Recent literature shows that, in most of the cases, migration (through remittances) increases the overall food security of rural and urban populations that receive aid (Zezza et al., 2011), while more controversial is the question of the food 
Figure 2 - Framework drawing the relationship between food security and migration (adapted from Foresight, 2011 and Warner et al., 2009).

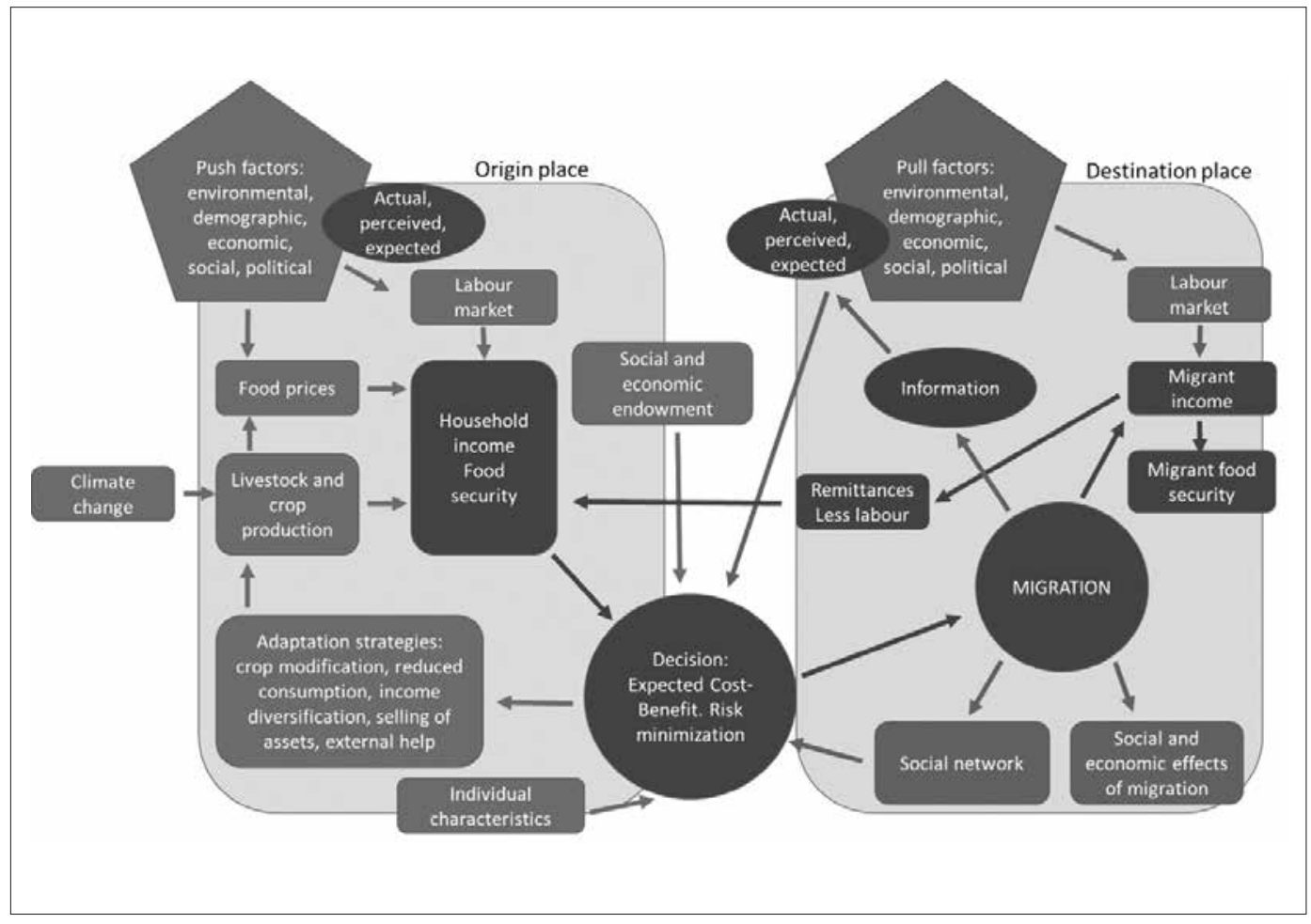

security of migrants that can sacrifice themselves to provide remittances or can acquire worse nutrition habits (Crush and Caesar, 2017). Depending on the initial social and economic endowment of households, migration may have four different effects (Warner and Afifi, 2014): a) it can improve household resilience; b) it can permit to survive without improvement; c) it can result as an erosive coming strategy (i.e. welfare decreases); d) finally, there are cases where migration is not an option (i.e. trapped populations).

Starting from these assumptions, we illustrate a framework of causal-effect links to explain the relationship between food security and migration (Figure 2). Other authors have built similar tools. McLeman and Smit (2006) used a model established in theories of migration behaviour. Perch-Nielsen et al. (2008) mainly consider the causal links driven by floods and sea level rise. Our framework is mainly an adaptation of the those developed in CARE and Foresight projects (Foresight, 2011; Warner et $a l ., 2009)$. The core of the relationship is set up on the following basic causal chain: food insecurity (actual or expected) causes the decision to migrate (or force the displacement); a share of the migrant income is sent home to alleviate household food insecurity; another share is used to guarantee the migrant food security. The framework (far from being complete) includes other important factors, such as the push and pull drivers (including external factors, household characteristics and individual characteristics). A driver of migration is migration itself since it tends to perpetuate (Perch-Nielsen et al., 2008). The framework also considers alternative coping strategies to migration (e.g. crop modification, reduced consumption, income diversification, selling of assets, external help) which could be used to increase food production, income and food security (Fawole and Ozkan, 2018). These alternative strategies can benefit of investments performed thanks to remittances (Zezza et al., 2011). 


\section{Selection of case studies}

Significant case studies were firstly selected following a Scopus search on "food security" and "migration" performed on 1 October 2017, without time restriction. Almost four hundred papers were found including theoretical works and case studies around the world, of which about nighty on Africa. However, many of these were only poorly related with the objectives of this paper, thus, on the base of the abstracts, we have selected 32 papers, related to 35 African case studies, that explicitly considered one or more of the links identified in Figure 2 or that could expand in other directions the causal-effect relations of the framework. Case studies were classified using the following items: country of origin of migration, destination (internal or external), duration and drivers of migration. Drivers have been classified as economic, climatic and concerning personal security (e.g. warfare and civil conflict situations). A summary of this information is presented in Table 2. The more interesting aspects of these papers are presented and discussed in the following sections with the purpose to validate and expand our framework.

\section{Results}

As indicated in Table 2, the majority of case studies (19) concerns exclusively internal migration. Only 16 cases concern external migration (of which, 6 in combination with internal migration and 10 as the only form of migration), and of these only 5 are related to migration out of the African continent ( 2 toward Middle Eastern countries). Cases include both permanent migration patterns (16), and cases (11) where migration is either temporary or seasonal; other situations include both patterns. Drivers of migration are often mixed and it is not always easy to make a separation between case studies driven by economic, climatic and personal security motivations. With a rough classification, in 6 case studies, climatic reasons represent clearly the main driver, in particular linked to rainfall variability and water shortage; in 8 case studies, migration is purely motivated by economic reasons, while in 3 cases warfare and conflicts are presented as the main driver of displacement. However, there are at least 18 case studies where more motivations are strictly interrelated. Movement from rural areas to urban areas is clearly

Table 2 - Main aspects of the 32 papers used for literature review of African case studies. Characteristics include the country of origin of migration, destination (I: internal; E: external; H: both), duration (P: permanent; $\mathrm{T}$ : temporary; B: both) and drivers of migration (N: economic; $\mathrm{C}$ : climatic; $\mathrm{W}$ : security; M: mixed). Framework links indicate the main contribution to the migration-food security framework.

\begin{tabular}{|l|l|l|l|l|l|}
\hline \multicolumn{1}{|c|}{ Paper } & \multicolumn{1}{|c|}{ Character. } & \multicolumn{1}{|c|}{ Framework links } & \multicolumn{1}{|c|}{ Paper } & \multicolumn{1}{c|}{ Character. } & \multicolumn{1}{|c|}{ Framework links } \\
\hline $\begin{array}{l}\text { Afifi } \text { et al. } \\
(2014)\end{array}$ & $\begin{array}{l}\text { Tanzania } \\
\text { H, B, M }\end{array}$ & $\begin{array}{l}\text { Migration more } \\
\text { probable for large } \\
\text { farmers attracted by } \\
\text { pull factors }\end{array}$ & $\begin{array}{l}\text { Loevinsohn } \\
(2015)\end{array}$ & $\begin{array}{l}\text { Malawi } \\
\text { I, T, C }\end{array}$ & $\begin{array}{l}\text { Migration driven by } \\
\text { famine may increase } \\
\text { HIV-infection }\end{array}$ \\
\hline Ajaero (2017) & $\begin{array}{l}\text { Nigeria } \\
\text { I, T, C }\end{array}$ & $\begin{array}{l}\text { Temporary migration } \\
\text { caused by floods }\end{array}$ & $\begin{array}{l}\text { Lynch } \text { et al. } \\
(2013)\end{array}$ & $\begin{array}{l}\text { Sierra Leone } \\
\text { I, P, W }\end{array}$ & $\begin{array}{l}\text { Forced urbanization } \\
\text { causes urban } \\
\text { farming as coping } \\
\text { strategy }\end{array}$ \\
\hline $\begin{array}{l}\text { Akçay and } \\
\text { Karasoy } \\
\text { 2017) }\end{array}$ & $\begin{array}{l}\text { Algeria } \\
\text { E, B, N }\end{array}$ & $\begin{array}{l}\text { Effect (long run) of } \\
\text { remittance on food } \\
\text { security }\end{array}$ & $\begin{array}{l}\text { Mathee and } \\
\text { Naicker } \\
(2016)\end{array}$ & $\begin{array}{l}\text { Southern } \\
\text { Africa region } \\
\text { H, P, M }\end{array}$ & $\begin{array}{l}\text { Locals and } \\
\text { international } \\
\text { migrants have } \\
\text { similar food security } \\
\text { and health status }\end{array}$ \\
\hline $\begin{array}{l}\text { Appeaning } \\
\text { Addo (2010) }\end{array}$ & $\begin{array}{l}\text { Ghana } \\
\text { I, P, M }\end{array}$ & $\begin{array}{l}\text { Rural to urban } \\
\text { migration has } \\
\text { positive effects on } \\
\text { urban farming }\end{array}$ & Mba (2010) & $\begin{array}{l}\text { Ghana } \\
\text { I, P, M }\end{array}$ & $\begin{array}{l}\text { Role of people that } \\
\text { returns from urban } \\
\text { to rural areas }\end{array}$ \\
\hline
\end{tabular}




\begin{tabular}{|c|c|c|c|c|c|}
\hline Paper & Character. & Framework links & Paper & Character. & Framework links \\
\hline $\begin{array}{l}\text { Atuoye et al. } \\
(2017)\end{array}$ & $\begin{array}{l}\text { Ghana } \\
\text { I, B, M }\end{array}$ & $\begin{array}{l}\text { Positive contribute } \\
\text { of remittances to } \\
\text { food security }\end{array}$ & $\begin{array}{l}\text { Mueller et al. } \\
(2014)\end{array}$ & $\begin{array}{l}\text { Malawi } \\
\text { I, P, N }\end{array}$ & $\begin{array}{l}\text { Positive effect of } \\
\text { rural resettlements } \\
\text { on food security }\end{array}$ \\
\hline $\begin{array}{l}\text { Berhanu and } \\
\text { White (2000) }\end{array}$ & $\begin{array}{l}\text { Ethiopia } \\
\text { I, T, M }\end{array}$ & $\begin{array}{l}\text { Migration driven by } \\
\text { droughts, famine and } \\
\text { conflicts }\end{array}$ & $\begin{array}{l}\text { Mwambene et } \\
\text { al. (2014) }\end{array}$ & $\begin{array}{l}\text { Tanzania } \\
\text { I, P }\end{array}$ & $\begin{array}{l}\text { Positive effects of } \\
\text { (forced) pastoral } \\
\text { communities' } \\
\text { migration on crops }\end{array}$ \\
\hline $\begin{array}{l}\text { Binet et al. } \\
(2012)\end{array}$ & $\begin{array}{l}\text { Senegal } \\
\mathrm{E}, \mathrm{B}, \mathrm{C}\end{array}$ & $\begin{array}{l}\text { Migration of fishers } \\
\text { contributed to the } \\
\text { depletion of fish } \\
\text { stocks }\end{array}$ & $\begin{array}{l}\text { Nawrotzki et } \\
\text { al. (2016) }\end{array}$ & $\begin{array}{l}\text { Burkina Faso } \\
\text { Senegal } \\
\text { E, T, C }\end{array}$ & $\begin{array}{l}\text { Unfavourable } \\
\text { climatic conditions } \\
\text { and low agricultural } \\
\text { production } \\
\text { decrease migration } \\
\text { possibilities }\end{array}$ \\
\hline Brown (2014) & $\begin{array}{l}\text { Uganda } \\
\text { I, P, M }\end{array}$ & $\begin{array}{l}\text { Effects of migration } \\
\text { on urban food } \\
\text { insecurity }\end{array}$ & $\begin{array}{l}\text { Nyantakyi-F. } \\
\text { and Bezner } \\
\text { Kerr (2017) }\end{array}$ & $\begin{array}{l}\text { Ghana } \\
\text { I, B, N }\end{array}$ & $\begin{array}{l}\text { Effects of land } \\
\text { enclosure on } \\
\text { women's rights to } \\
\text { use land, migration } \\
\text { and increasing food } \\
\text { insecurity }\end{array}$ \\
\hline Cour (2001) & $\begin{array}{l}\text { Sahel } \\
\text { E, P, N }\end{array}$ & $\begin{array}{l}\text { Positive effects of } \\
\text { migration on natural } \\
\text { resources use }\end{array}$ & $\begin{array}{l}\text { Pendleton et } \\
\text { al. }(2014)\end{array}$ & $\begin{array}{l}\text { Namibia } \\
\text { E, B, M }\end{array}$ & $\begin{array}{l}\text { Role of rural-urban } \\
\text { food transfers for } \\
\text { migrants }\end{array}$ \\
\hline Crush (2013) & $\begin{array}{l}\text { Southern } \\
\text { Africa region } \\
\mathrm{H}, \mathrm{P}, \mathrm{M}\end{array}$ & $\begin{array}{l}\text { Rural households } \\
\text { do not invest } \\
\text { remittances in } \\
\text { agriculture but in } \\
\text { basic necessities }\end{array}$ & $\begin{array}{l}\text { Rademacher- } \\
\text { Schulz et al. } \\
(2014)\end{array}$ & $\begin{array}{l}\text { Ghana } \\
\text { I, T, M }\end{array}$ & $\begin{array}{l}\text { Temporary migration } \\
\text { as traditional } \\
\text { strategy to face the } \\
\text { economic and food } \\
\text { security needs }\end{array}$ \\
\hline $\begin{array}{l}\text { Crush and } \\
\text { Tawodzera } \\
(2016)\end{array}$ & $\begin{array}{l}\text { Zimbabwe } \\
\text { E, P,N }\end{array}$ & $\begin{array}{l}\text { Zimbabwean } \\
\text { households living } \\
\text { in RSA are food } \\
\text { insecure as an effect } \\
\text { of remittances } \\
\end{array}$ & Reis (2015) & $\begin{array}{l}\text { Cape Verde } \\
\text { E, T, M }\end{array}$ & $\begin{array}{l}\text { Geo-climatic } \\
\text { conditions and rise } \\
\text { in food prices as } \\
\text { causes of migration } \\
\text { (role of remittances) }\end{array}$ \\
\hline $\begin{array}{l}\text { Endalew et al. } \\
\text { (2015) }\end{array}$ & $\begin{array}{l}\text { Ethiopia } \\
\text { I, T, M }\end{array}$ & $\begin{array}{l}\text { Migration driven by } \\
\text { droughts, famine and } \\
\text { conflicts }\end{array}$ & $\begin{array}{l}\text { Sporton et al. } \\
(1999)\end{array}$ & $\begin{array}{l}\text { Botswana } \\
\text { I, B, M }\end{array}$ & $\begin{array}{l}\text { Complex migration } \\
\text { patterns driven by } \\
\text { land privatization }\end{array}$ \\
\hline $\begin{array}{l}\text { Fransen and } \\
\text { Mazzucato } \\
(2014)\end{array}$ & $\begin{array}{l}\text { Burundi } \\
\text { E, P, M }\end{array}$ & $\begin{array}{l}\text { Effect of remittance } \\
\text { (short run) on food } \\
\text { security }\end{array}$ & $\begin{array}{l}\text { Suckall et al. } \\
\text { (2017) }\end{array}$ & $\begin{array}{l}\text { Malawi } \\
\mathrm{H}, \mathrm{B}, \mathrm{C}\end{array}$ & $\begin{array}{l}\text { Climate change } \\
\text { increases barriers to } \\
\text { migration (poverty } \\
\text { trap) }\end{array}$ \\
\hline Ibnouf (2011) & $\begin{array}{l}\text { Sudan } \\
\text { I, P, W }\end{array}$ & $\begin{array}{l}\text { Role of women in } \\
\text { achieving household } \\
\text { food security when } \\
\text { men migrate }\end{array}$ & $\begin{array}{l}\text { Warner and } \\
\text { Afifi (2014) }\end{array}$ & $\begin{array}{l}\text { Ghana, } \\
\text { Tanzania } \\
\text { I, T, M }\end{array}$ & $\begin{array}{l}\text { Urbanization linked } \\
\text { to economic reasons } \\
\text { and stress on food } \\
\text { production systems }\end{array}$ \\
\hline Jung (2013) & $\begin{array}{l}\text { Senegal } \\
E, P, N\end{array}$ & $\begin{array}{l}\text { Positive contribute } \\
\text { of remittances to } \\
\text { food security }\end{array}$ & $\begin{array}{l}\text { Warner et al. } \\
(2010)\end{array}$ & $\begin{array}{l}\text { Egypt } \\
\text { Mozambico } \\
\text { I, P, M }\end{array}$ & $\begin{array}{l}\text { Negative } \\
\text { (unsustainable) } \\
\text { experiences of rural } \\
\text { resettlements }\end{array}$ \\
\hline $\begin{array}{l}\text { Karamba et al. } \\
\text { (2011) }\end{array}$ & $\begin{array}{l}\text { Ghana } \\
\mathrm{H}, \mathrm{P}, \mathrm{N}\end{array}$ & $\begin{array}{l}\text { Migrants shift to less } \\
\text { nutritious } \\
\text { foods }\end{array}$ & $\begin{array}{l}\text { Young and } \\
\text { Jacobsen } \\
(2013)\end{array}$ & $\begin{array}{l}\text { Sudan } \\
\text { I, T, W }\end{array}$ & $\begin{array}{l}\text { Effects of } \\
\text { conflicts on forced } \\
\text { urbanization and } \\
\text { food insecurity }\end{array}$ \\
\hline
\end{tabular}


the most common pattern of migration. Howev$\mathrm{er}$, there is a large number of papers where more complex patterns are considered, each of them would deserve a specific consideration.

Among the regions of the continent where we find more studies there are Western Africa (15 case studies), Eastern Africa (8 case studies) and Southern Africa ( 9 case studies). 2 Only in the case of Southern and Western Africa we can count with a rough regional framework of migration and food security, while the case studies of Eastern Africa are much more isolated cases. For Southern and Western Africa, analysis is facilitated by a few transnational studies where food security is discussed at regional level and where migration flows from one or more countries of that region to one or more countries of the same region. For Eastern Africa, on the contrary, we mainly count with internal migration studies.

Finally, very few information is available on Northern Africa (two case studies, in Algeria and Egypt, respectively), and Central Africa (only one study in Burundi). In the following sections, are shown the main patterns and trends by geographical region.

\subsection{Western Africa}

Undernourishment of population has moved from $15.1 \%$ in 2000 to $10 \%$ (in 2010) and $10.4 \%$ in 2015 (FAO et al., 2017). Intraregional migration is fostered by visa-free movement among the Economic Community of West African States (ECOWAS) members, the relatively small sizes of many countries and the strong networks among the many ethnic groups scattered across the sub region (IOM, 2011). As stressed by the project "In search of shelter" (Warner et al., 2009), migration, particularly circular mobility, is a traditional coping mechanism in this region, representing a livelihood diversification strategy. However, in some areas, these traditional patterns have changed in recent decades due to land degradation and drought. As clearly drawn by Cour (2001, the only reviewed paper with regional coverage), we assist now to a large migration movement from the Sahel countries to the coastal and urban agglomerations. Furthermore, short-term migration is developing into a pattern of creeping onward movement (Warner et al., 2009).

The areas of immigration in coastal states now contain half of the regional population as against $31 \%$ in 1960 , with average density that is double that of the areas of emigration (Cour, 2001). However, in Cour's opinion, "these migratory flows have on the whole contributed to a better adjustment between population, natural resources and the needs of the market economy". On average, per capita value added, and therefore income, in the urban population is double that in rural area.

The large-scale migration pattern of Western Africa can be seen, at smaller scale, for some of the countries inside the region, and in particular for Ghana, for which 7 case studies have been found, most of which deal with the main relations drawn in Figure 2. Inside this country, we assist to an internal migration process, driven by economic and climatic reasons (rainfall variability and stress on food production systems), from rural areas in the north to rural and urban areas in the south (Warner and Afifi, 2014). Seasonal (in dry season) or temporary circulation of men is a traditional coping strategy on these routes in order to face the economic and food security needs of rural households, but migration is now shifting to permanent decisions. In bad years (such as 2011), we assist to temporary migration also in the rainy season, which can be considered an erosive coping strategy (Rademacher-Schulz et al., 2014).

For Atuoye et al. (2017), although remittances have the effect of reducing the likelihood of households becoming severely food insecure, they are not sufficient in making households completely food secure. Karamba et al. (2011), highlight that migrant food expenditures may result in a shift towards the consumption of potentially less nutritious categories of food.

Other findings go beyond the links of Figure 2. Firstly, urban farming is a developing activi-

\footnotetext{
2 Regions of the Africa Union are used for the division.
} 
ty. Appeaning Addo (2010) highlights that urban farmers of Accra, most of them migrating from rural areas and with some level of experience in farming, appreciate their activity: in fact, 66 percent of urban farmers have no intention to stop farming even if they were offered regular paid employment.

Secondly, according to Mba (2010), many migrants return to rural communities when they grow old since they may have retired from employment and can no longer cope with the high cost of living in Ghanaian towns. They also become eligible for leadership roles as lineage elders. On the other hand, some of them may choose to remain in the cities where social amenities and other benefits of modernization are concentrated.

Thirdly, Ghanaian patterns of migration do not exclusively follow the classical direction from rural to urban areas; very specific pushing drivers and consequences can also be found. Many economic opportunities are found in the fertile farmlands in the south (even if increasing mechanization is leading to fewer jobs) and in the mining sub-sector. From 2004 to 2010, the Ghanaian government, village chiefs and family heads allocated between 89,000 and 1,075,000 hectares of land for foreign-based investments in large-scale agriculture, mining and biofuel production (Nyantakyi-Frimpong and Bezner Kerr, 2017). Land enclosure has dispossessed pre-existing usufruct rights held by local farmers in several villages intensifying the erosion of women's rights to use land, increasing food insecurity and rural outmigration of landless householders (Nyantakyi-Frimpong and Bezner Kerr, 2017).

Inside the Western Africa framework, Senegal has peculiar migration patterns. Binet et al. (2012) consider the migration of fishers to neighbour coastal countries. The authors of this paper stress that migration of Senegalese fishers (driven by repeated droughts and local reduction of fish stocks) has largely contributed to a generalized depletion of fish stocks within the whole West African region. As in many other contexts, even in this very specific case, migrant fishing had historically occurred upon a local seasonal cycle, punctuated by an annual return to the home village during the annual rice planting and harvest seasons; however now, fishers have no other choice but to extend their migration area (end period) and exploit new stocks.

Jung (2013) considers another peculiar migration circuit in Western Africa, which is the recent increasing immigration to Cape Verde from member states of the Economic Community of West African States, and in particular from Senegal. One of the most interesting aspects is that while the islands are chosen as a destination (thanks to the extension of the tourism sector), at the same time Cape Verdeans continue to seek their luck outside their home country (Reis, 2015), due to geo-climatic conditions and rise in food prices (remittances have an important role for rural households). One fact is that it is cheaper to migrate to Cape Verde than to Europe, even if job opportunities are not as good. Mostly young men emigrate from Senegal for economic reasons. Remittances are mainly spent for alimentation, but also for education, payments of rent, electricity or water and medical bills. Only a small part is used for investment, normally in housing or land, as it represents a sign of migration success.

Nawrotzki et al. (2016) observations for Senegal and Burkina Faso are of particular interest in the understanding of the relations between food security and migration: in these two countries, international migration increases under beneficial climatic conditions and decreases when conditions become less favourable. In fact, when climate adversely impact agricultural production and livelihoods, the resource base of households may degrade, making it difficult to finance an expensive international move. This is particularly true in marginalized departments, while in areas with very good food security conditions climate adversity can foster migration.

Other papers concerning West African countries are those of Ajaero (2017) and Lynch et al. (2013). The first deals with the internal displacement of Nigerian population affected by floods and their subsequent return back to their places of origin. On the other hand, Lynch et al. (2013) deal with the forced urbanization of Sierra Leone to escape from violence during the civil war. This caused dislocation of food production and emergence of urban farming as a coping strategy for Freetown residents. 


\subsection{Southern Africa}

The percentage of undernourished people was $8 \%$ in 2015 , thus slightly increasing compared to $7.1 \%$ in 2000 and $6.7 \%$ in 2010 (FAO et al., 2017). Intraregional labour migration is well established, since significant numbers of people have traditionally migrated from countries such as Malawi, Lesotho, Zimbabwe and Swaziland to work in key sectors such as mining in South Africa (RSA) and Botswana (IOM, 2011).

Literature on food security and migration is Southern Africa is characterized by several studies focusing on the food security status of urbanized migrants (i.e. the right side of Figure 2): it includes papers on the urbanization process in the RSA (Crush and Tawodzera, 2016; Mathee and Naicker, 2016), in Namibia (Pendleton et al., 2014) and in all the main cities of the region (Crush 2013). Both internal and intra-regional migration are considered, in particular from Zimbabwe (driven by poverty, unemployment and food insecurity) to RSA. RSA is, in fact, the state more used by case studies as destination of international migration, attracting people in urban and mining centres. The main conclusion is that urban migrants, mainly involved in informal work, remain in large part food insecure, more than local population (Crush, 2013); for Crush and Caesar (2017), non-migrant households were more likely to grow some of their own food in urban gardens.

Mathee and Naicker (2016) stress how migration has caused waves of xenophobic violence across South Africa. Both RSA respondents and international migrants in settings of urban poverty in Johannesburg had remarkably similar food security and health status. Over $80 \%$ of the 500 Zimbabwean households interviewed by Crush and Tawodzera (2016) were food insecure in terms of the amount of food to which they had access, also as an effect of the remittances that they had to send to their families in Zimbabwe. On the other side, rural households do not invest remittances in agriculture but in basic necessities (Crush 2013).

Pendleton et al. (2014) observe that "migrant households are not significantly more food insecure than the other residents of Windhoek's poorer areas $[\ldots]$. The explanation for this is rural-urban food transfers". In other words, reciprocal urbanisation involves sending cash remittances to rural family members and receiving agricultural produce in return.

A relatively abundant literature exists also for Malawi, focusing on the effects of climate change on food security and migration. Suckall et al. (2017) considers that climate change may likely increase barriers to migration rather than increasing migration flows (i.e., poverty trap). Loevinsohn (2015) evaluates the effects of famine and migration on HIV-infection (something not explicitly included in our framework), linked to the behaviour of urbanized individuals that, separated from partners and family, are more likely to engage in transactional and non-marital sex.

Both a third paper on Malawi (Mueller et al., 2014) and a case study on Mozambique (Warner et al., 2010) deal with rural to rural resettlements. However, the two situations are quite different. In the first case, the project aimed to reallocate underutilized land from failing tobacco and tea estates to land-constrained, food insecure, low-income households. Participation was voluntary and resettled households achieved greater long-term food security, owing to additional land coupled with a more diversified crop portfolio. In the case of Mozambique, on the contrary, resettlement was a post-emergence measure for flood-affected (i.e. displaced) people and it moved rural villages together. The study concluded that government assistance had prevented the necessity for people to migrate longer distances or across borders but resettled people remained heavily dependent on governmental and international aid. Finally, resettlement contributed to deforestation, soil erosion and water scarcity (Warner et al., 2010).

Finally, Sporton et al. (1999) consider a complex migration pattern in Botswana, driven by the privatization of land and the creation of fenced, borehole-focused, leasehold ranches in an area characterized by seasonal mobility of pastoral and hunter-gatherer populations. Depending on the place (as a consequence of ethnic tensions and droughts), this has caused multiple dynam- 
ics, including progressive sedentarisation, depopulation, displacement, transient population (dependent on the goodwill of the ranch owners who control access to environmental resources), re-migration from centres established to absorb ranch populations

\subsection{Eastern Africa}

The sub region has the highest rate of undernourishment of the continent $(31.1 \%$; it was $39.3 \%$ in 2000 , and $30.9 \%$ in 2010) (FAO et al., 2017). Eastern Africa continues to experience considerable levels of outward labour mobility, driven by poverty, low wages and high unemployment. Environmental change and disasters (variability in precipitation and high occurrence of drought) are increasing and are influencing human movement and displacement. Gulf States represent a preferential destination (IOM, 2011).

Tanzania and Ethiopia are the Eastern Africa States where the major number of studies on migration and food security have been carried out. Most of them deal with internal rural to urban migration driven by some climatic concern (mainly rainfall variability and water shortage), often associated with economic motivations in the case of Tanzanian and with security (i.e. conflicts) motivations in Ethiopia (Berhanu and White, 2000; Endalew et al., 2015). It is probable, as indicated by the Foresight project, that these patterns are very common to other countries of the region (Foresight, 2011), even if climate change can produce mixed effects (increasing or decreasing crop yields) depending on geographical patterns (Mulwa et al., 2016).

As in other regions of Africa, in Tanzania, seasonal migration is a typical adaptation strategy for rural communities, but severe droughts (in particular from 1998 to 2005) made people to migrate for longer periods or permanently (Afifi et al., 2014). According to Afifi et al. (2014) "it is usually the large farmers who possess sufficient means to leave, and their migration decision might not necessarily be related to food insecurity but rather pull factors in the areas of destination".
Beside rural to urban flows, rural to rural movements can also result to be critical. As known, livestock keepers' migration in search of pasture and water is something very common, but modernity may change traditional patterns. Establishment of new and expansion of existing game reserves by the Tanzanian government and other land acquisitions by investors have further implicated to amplify the shortage of grazing and cropping land in the country. Mwambene et al. (2014) illustrates a case of forced migration of agro-pastoral and pastoral communities. This implicated both benefits and conflicts in the new settlements' areas. The arrival of agro-pastoralists in areas where livestock was not traditionally available, improved the food security of local population: in fact, farmers were being persuaded to use ox-driven ploughs, soil was fertilized, and availability of meat and milk increased (Mwambene et al., 2014).

Brown (2014) confirms that accelerating migration from drought stricken and/or insecure rural areas is also a critical aspect of Uganda (a country that is largely food sufficient and is a major regional food exporter). He considers that urban income distribution is highly unequal, food prices are high and the majority of urban residents suffer food insecurity.

Sudan, and in particular Darfur, is a country where conflict and crisis have had impact on mobility, restricting and even blocking physical movement of people and livestock, leading to the virtual collapse of livelihood systems (Young and Jacobsen, 2013). In this complex framework, Ibnouf (2011) investigates the essential role of women in achieving household food security, while men are more likely to migrate seasonally and even permanently (mainly in mechanized agriculture schemes) as an effect of drought and civil conflicts. For the author, "the root causes of tribal tensions in the western Sudan region lie deeply in an old conflict over natural resources between sedentary farmers and nomadic herdsmen". Women, which perform $60 \%$ of all agricultural work in the traditional agricultural sector, result to have limited access to credit and inputs because of gender discrimination and lack collateral. 


\subsection{Other regions}

In Northern Africa the percentage of undernourishment increased from $6.8 \%$ in 2000 to $8.3 \%$ in 2015 (5.1\% in 2010) (FAO et al., 2017). Due to external dependence, food security is strictly linked to world food price volatility (Lacirignola et al., 2015). Migration to Europe and Gulf States is a defining feature of the region, and has developed over several decades. North African sub region is also both a migrant transit area and a destination of international migrants and refugees (CIHEAM, 2018; IOM, 2011). On the other side, in Central Africa, we find a $24.4 \%$ of population undernourished $(37.4 \%$ in $2000 ; 23.8 \%$ in 2010 ) (FAO et al., 2017). Conflict and instability have played a larger role in displacement mainly to neighbouring countries (IOM, 2011).

Both Akçay and Karasoy (2017) in Algeria, and Fransen and Mazzucato (2014) in Burundi, evaluate the effects of remittances on food security, including the short-run effect of the disposable income and the long-run effect of investments. These are also two of the few papers that explicitly consider migration out of the African continent. Empiric results are completely different. Akçay and Karasoy (2017) concludes that, in Algeria, remittances influence calorie consumption significantly only in the long run. Fransen and Mazzucato (2014), on the contrary, reckon that in Burundi "remittances have strong effects on non-productive assets, such as living conditions and food security, and weak effects on productive assets, such as asset ownership". However, the authors warn that it is not yet clear whether wealthier households had more migration opportunities and were therefore more likely to receive remittances, or whether households became wealthier because of remittances. For sure, poorer and wealthier households allocate remittances differently and remittances from abroad are largely absent in rural areas.

Finally, Warner et al. (2010) consider the problems of soil and water salinity in governmental resettlements in Nile Delta. People who were resettled were either unemployed young men from urban slums or farmers affected by a law that favoured landowners who could easily drive away share croppers from desirable agri- cultural areas. Many migrants did not stay in the new settlements, either leaving to other regions or returning to their original regions.

\section{Discussion}

Despite the low number of papers that explicitly try to develop a causal link between food security and migration for the African continent, and despite the heterogeneity and geographical dispersion of the case studies, it is possible to stress a few common points derived from the different situations reviewed. Some of these considerations broadly confirm the main drivers and connections that have been highlighted in the general framework of Figure 2 (see Table 2). However, other aspects are probably less obvious and would need further investigation in the future.

Drivers of migration are never simple and well defined (McLeman and Smit, 2006). Quite often, more than one cause (including economic, climatic and security drivers) contributes to migration. Often, food (in)security results to be the connecting chain between several drivers and the final decision to migrate. Berazneva and Lee (2013) showed how 14 African countries experienced food riots fostered by high levels of poverty, restricted food access and availability, high level of urbanization and civil society, and oppressive regimes. Due to these interconnections, there are many situations where it is difficult to define if migration is voluntary or forced. Cases may change considerably depending on the structure and endowments of each household. From structural and familiar characteristics, different strategies based on opportunity costs or risk minimization do emerge (Post et al., 2016).

Relationships inside the household and between households should be analysed more in depth. Individuals often migrate following household strategies and investments (Zezza et al., 2011). Multi-nodal households are emerging, stretched between two or more locations (Crush, 2013). Migrants feel moral duties for their families at home, and can sacrifice their own food security to comply with their obligations as seen for Senegalese migrants in Cape 
Verde (Jung, 2015) and migrants in Southern Africa cities (Crush, 2013; Crush and Tawodzera, 2016). In specific cases, food security in the city is temporarily buttressed by informal flows of agricultural products from the rural family; this has been attested in Namibian (Pendleton et al., 2014) and Ethiopian (Tolossa, 2010) towns. Return back from urban to rural areas is probably a phenomenon that is not sufficiently considered (Mba, 2010).

Many aspects emerging from the case studies are not explicitly illustrated by the framework of Figure 2. Several papers see urban farming as a solution of food security problems in African cities, as seen for the case studies in Accra (Appeaning Addo, 2010) and Freetown (Lynch et al., 2013). However, for Crush (2013), "the obsession with urban agriculture $[. .$.$] derives from$ the misplaced idea that increased food production is the key to urban food security" when the primary determinant is the absence of a regular income to purchase food. Certainly, people coming from rural areas can provide knowledge and expertise to improve urban farming, but access to land can be difficult for migrants.

If rural to urban movement is the most common pattern of migration, interesting cases deal with rural to rural migration. Voluntary, often seasonal, migration of individuals is frequently driven by development of modern-industrial farming; similar cases have been seen in Ghana and Sudan (Young and Jacobsen, 2013). Other situations deal with institutional resettlements of communities or families from one area to a new one. This can be a voluntary process (e.g. driven by economic reasons) as attested in a few case studies in Malawi (Mueller et al., 2014) and Egypt (Warner et al., 2010); it can be driven by emergences, as in the case of exceptional floods in Mozambique (Warner et al., 2010); or it can be driven by land acquisition and population expulsion as seen in Tanzania (Mwambene et al., 2014) and Botswana (Sporton et al., 1999). More in general, land grabbing, such as the establishment of new (and expansion of existing) game reserves, and the land acquisitions by investors for large-scale agriculture, pastures, mining and biofuel production, represents a serious driver which directly affect both food security and migration processes. This has been observed in many situations and deserves an explicit place in our framework. It is clear that lack of land tenure security reduces the motivation to invest in capital assets and conservation of resources.

Another aspect related to food security and migration (and in particular urbanization) that has been considered in some paper is the diffusion of diseases. Loevinsohn (2015) deals with this theme for HIV in Malawi, while Khan and Sesay (2015) deals with Ebola in West Africa.

Finally, gender issues need a special attention. Generalization is difficult on this theme, but important remarks can be done. In more than one case, emergencies or critical situations cause the erosion of women rights. In Nigeria, after severe flood damage, forced displacement and final return to original areas, many widows had their land confiscated by their husband's brothers (Ajaero, 2017). In Malawi, resettlement programs compromised the traditional practices of matrilineal land inheritance (Mueller et al., 2014). In Ghana, land enclosure has caused land scarcity, and, as a direct consequence, erosion of women's rights on vegetable pots (NyantakyiFrimpong and Bezner Kerr, 2017). In Sudan, where men migrate leaving their wives to cultivate the land, women have limited access to credit and inputs because of gender discrimination and lack collateral (Ibnouf, 2011).

\section{Conclusion}

Building on previous literature we have developed a general framework to connect food security aspects with migration. Several African cases studies deal with and validate the key links of this framework. In particular: i) food insecurity may cause the decision to migrate (or force the displacement), and ii) a share of the migrant income is sent home to alleviate household food insecurity.

In Africa, the majority of migration happens within the continent. An international move is often costly to initiate. Confirming the assumptions of theoretical works (Marchiori et al., 2012), the case studies have shown patterns of creeping onward movement (Warner et al., 2009): rural people move firstly to close urban 
or rural areas (characterized by modern agriculture), then to larger towns; urban people move to neighbour countries and, only if they can, to other continents. Climate change can or cannot foster this pattern. Adverse climate conditions undermine income generation, thus households may lack the financial resources to send a member elsewhere (Nawrotzki et al., 2016). A poverty trap prevents most insecure households to leave marginal lands.

Many aspects need further analysis. For example, when (i.e. in which conditions) does food insecurity encourage to migrate and when represent a poverty trap? On the other hand, when do migration and remittances cause food insecurity for migrant components of the households? How are remittances used and why? More in general, household strategies to reduce risks and informal contracts among family members have to be investigated. Literature review has highlighted that two important issues not explicitly included in our framework deal with land tenure and gender aspects. For all these issues, considering the role of social institutions and culture is essential to avoid the pitfall of environmental determinism (McGregor, 1994).

Studies dealing with the migration-food security connection are far from being complete and uniformly distributed along the continent. There are areas (e.g. Western Africa, South Africa, Tanzania, and Ethiopia) where this theme has begun to attract the interest of researchers and others (e.g. Northern and Central Africa) where studies have not started yet. A more organized way to collect information on the main causes of migration could help to tackle with the problems that poor people face every day: drought, food insecurity, land grabbing, socio-political conflicts, etc. With the right information, international organizations and national agencies could focus much more clearly on the areas and the subjects that need more economic support and development. In particular, it is important to question the role of agriculture and rural development in preventing the exodus to urban areas (CIHEAM, 2018). Changes in agricultural practices are required, without forgetting other fundamentals that are necessary to improve rural living standards, such as logistics, services, cultural opportunities and guarantees on civil and economic rights; furthermore, the creation of new job opportunities is needed to reduce household risks. Without a coordinated strategy tackling all these issues, higher farming incomes could only encourage new migration of the young population. Public funds and private resources, starting from those coming from remittances, should be used in the best way for sustainable investments and development. In this context, participatory initiatives based on community empowerment can help to lift rural and young people out from their triple spatial, economic and social marginalisation (CIHEAM, 2018).

\section{References}

Afifi T., Liwenga E., Kwezi L., 2014. Rainfall-induced crop failure, food insecurity and out-migration in Same-Kilimanjaro, Tanzania. Climate and Development, 6(1): 53-60, doi:10.1080/17565529. 2013.826128.

Ajaero C.K., 2017. A gender perspective on the impact of flood on the food security of households in rural communities of Anambra state, Nigeria. Food Security, 9(4): 685-695, doi:10.1007/s12571-0170695-x.

Akçay S., Karasoy A., 2017. Remittances and Calorie Consumption Nexus in Algeria Selc. International Migration, 55(4), doi:10.1111/imig.12348.

Appeaning Addo K., 2010. Urban and peri-urban agriculture in developing countries studied using remote sensing and in situ methods. Remote Sensing, 2(2): 497-513, doi:10.3390/rs2020497.

Atuoye K.N., Kuuire V.Z., Kangmennaang J., Antabe R., Luginaah I., 2017. Residential Remittances and Food Security in the Upper West Region of Ghana. International Migration, 55(4): 18-34, doi:10.1111/ imig. 12310.

Berazneva J., Lee D.R., 2013. Explaining the African food riots of 2007-2008: An empirical analysis. Food Policy, 39: 28-39, doi:10.1016/j.foodpol.2012.12.007.

Berhanu B., White M., 2000. War, Famine, and Female Migration in Ethiopia, 1960-1989. Economic Development and Cultural Change, 49(1): 91-113, doi:10.1086/452492.

Binet T., Failler P., Thorpe A., 2012. Migration of Senegalese fishers: a case for regional approach to management. Maritime Studies, 11(1): 1, doi:10.1186/2212-9790-11-1. 
Black R., Adger W.N., Arnell N.W., Dercon S., Geddes A., Thomas D., 2011. The Effect of Environmental Change on Human Migration. Global Environmental Change, 21(S1): S3-S11.

Brown A.M., 2014. Uganda's Emerging Urban Policy Environment: Implications for Urban Food Security and Urban Migrants. Urban Forum, 25(2): 253264, doi:10.1007/s12132-014-9224-6.

Carling J., Collins F., 2018. Aspiration, desire and drivers of migration. Journal of Ethnic and Migration Studies, 44(6): 909-926, doi:10.1080/136918 3X.2017.1384134.

CIHEAM, 2018. Migration and Inclusive Rural Development in the Mediterranean, Mediterra Report. https://www.ciheam.org/en/publications/mediterra/ details?pub=MEDITERRA_2018\&id=33.

Cour J.M., 2001. The Sahel in West Africa: Countries in transition to a full market economy. Global Environmental Change, 11(1): 31-47. http://www.scopus.com/inward/record.url?eid $=2-\mathrm{s} 2.0-0035108383 \&$ partnerID $=40 \& \mathrm{~m}$ $\mathrm{d} 5=5 \mathrm{c} 85 \mathrm{c} 2 \mathrm{ce} 75 \mathrm{a} 0 \mathrm{~b} 3 \mathrm{e} 2027205 \mathrm{a} 317 \mathrm{a} 3 \mathrm{eb} 31$.

Crush J., 2013. Linking Food Security, Migration and Development. International Migration, 51(5): 6175, doi:10.1111/imig.12097.

Crush J., Caesar M., 2017. Introduction: Cultivating the Migration-Food Security Nexus. International Migration, 55(4): 10-17, doi:10.1111/imig. 12360.

Crush J., Tawodzera G., 2016. Migration and Food Security: Zimbabwean Migrants in Urban South Africa. AFSUN, Urban Food Security Series, 23. Available at: http://www.afsun.org/wp-content/uploads/2016/06/AFSUN23.pdf.

Endalew B., Muche M., Tadesse S., 2015. Assessment of food security situation in Ethiopia: A review. Asian Journal of agricultural research, 9(2): 55-68.

FAO, 2016. Migration, Agriculture and Rural Development. Available at: http://www.fao.org/3/ai6064e.pdf.

FAO, 2017. FAOSTAT, Food Balance Sheets. http:// www.fao.org/faostat/en/\#data/FBS.

FAO, IFAD, UNICEF, WFP, WHO, 2017. The State of Food Security and Nutrition in The World 2017. Rome: FAO. Available at: http://www.fao.org/3/aI7695e.pdf.

FAO, IFAD, WFP, 2015. The State of Food Insecurity in the World 2015. Rome: FAO. Available at: http:// www.fao.org/3/a-i4646e.pdf.

Fawole W.O., Ozkan B., 2018. Food Insecurity Risks Perception and Management Strategies Among Households: Implications for Zero Hunger Target in Nigeria. New Medit, 17(2): 29-42, doi:10.30682/ nm1802c.
Findlay A.M., 2011. Migrant destinations in an era of environmental change. Global Environmental Change, 21(S1): S50-S58, doi:10.1016/j.gloenvcha.2011.09.004.

Foresight, 2011. Foresight: Migration and global environmental change. Final project report. London: The Government Office for Science. Available at: https://sustainabledevelopment.un.org/content/ documents/867migrationscience.pdf.

Fransen S., Mazzucato V., 2014. Remittances and household wealth after conflict: A case study on urban burundi. World Development, 60: 57-68, doi:10.1016/j.worlddev.2014.03.018.

Fukuda-Parr S., 2014. Introduction: Food Scarcity and Migration. Social Research, 81(2): 273-275, doi:10.2307/26549615.

Ibnouf F.O., 2011. Challenges and possibilities for achieving household food security in the Western Sudan region: The role of female farmers. Food Security, 3(2): 215-231, doi:10.1007/s12571-0110118-3.

IOM, 2011. World Migration Report 2018. World Migration Report. Geneva: IOM. doi:10.1017/ CBO9781107415324.004.

Jäger J., Frühmann J., Grünberger S., Vag A., 2009. EACH-FOR - Environmental change and forced migration scenarios. Project synthesis report. Middle East. Budapest: EACH FOR.

Jung P., 2015. Migration, Remittances and Development: A case study of Senegalese labour migrants on the island Boa Vista, Cape Verde. Cadernos de Estudos Africanos, 29, doi:10.4000/cea.1800.

Karamba W.R., Quiñones E.J., Winters P., 2011. Migration and food consumption patterns in Ghana. Food Policy, 36(1): 41-53, doi:10.1016/j.foodpol.2010.11.003.

Khan A.S., Sesay S.S., 2015. Seafood insecurity, bush meat consumption, and public health emergency in West Africa: Did we miss the early warning signs of an Ebola epidemic?. Maritime Studies, 14(1): 3, doi:10.1186/s40152-015-0020-2.

Lacirignola C., Adinolfi F., Capitanio F., 2015. Food security in the Mediterranean countries. New Medit, 14(4): 2-10.

Loevinsohn M., 2015. The 2001-03 famine and the dynamics of HIV in Malawi: A natural experiment. PLoS ONE, 10(9): 1-21, doi:10.1371/journal. pone. 0135108 .

Lynch K., Maconachie R., Binns T., Tengbe P., Bangura K., 2013. Meeting the urban challenge? Urban agriculture and food security in post-conflict Freetown, Sierra Leone. Applied Geography, 36: 31-39, doi:10.1016/j.apgeog.2012.06.007. 
Marchiori L., Maystadt J.F., Schumacher I., 2012. The impact of weather anomalies on migration in sub-Saharan Africa. Journal of Environmental Economics and Management, 63(3): 355-374, doi:10.1016/j.jeem.2012.02.001.

Mathee A., Naicker N., 2016. The socioeconomic and environmental health situation of international migrants in Johannesburg, South Africa. South African Medical Journal, 106(1): 70-75, doi:10.7196/ SAMJ.2016.v106i1.10215.

Mba C.J., 2010. Population Ageing in Ghana: Research Gaps and the Way Forward. Journal of Aging Research, 2010: 1-8, doi:10.4061/2010/672157.

McGregor J.A., 1994. Climate change and involuntary migration: implications for food security. Food Policy, 19(2): 120-132, doi:10.1016/03069192(94)90065-5.

McLeman R., Smit B., 2006. Migration as an adaptation to climate change. Climatic Change, 76(1-2): 31-53, doi:10.1007/s10584-005-9000-7.

Mueller V., Quisumbing A., Lee H.L., Droppelmann K., 2014. Resettlement for food security's sake: insights from a Malawi land reform project. Land economics, 90(2): 222-236, doi:10.1353/ lde.2014.0017.

Mulwa R., Rao K.P.C., Gummadi S., Kilavi M., 2016. Impacts of climate change on agricultural household welfare in Kenya. Climate Research, 67: 8797, doi:10.3354/cr01357.

Mwambene P.L., Mbwile R.P., Hoeggel F.U., Kimbi E.C., Materu J., Mwaiganju A., Madoffe S., 2014. Assessing dynamics of forced livestock movements, livelihoods and future development options for pastoralists/agro-pastoralists in $\mathrm{Ru}$ vuma and Lindi Regions, in the Southern Tanzania. Livestock Research for Rural Development, 26(1).

Nawrotzki R.J., Schlak A.M., Kugler T.A., 2016. Climate, migration, and the local food security context: introducing Terra Populus. Population and Environment, 38(2): 164-184, doi:10.1007/s11111016-0260-0.

Nyantakyi-Frimpong H., Bezner Kerr R., 2017. Land grabbing, social differentiation, intensified migration and food security in northern Ghana. Journal of Peasant Studies, 44(2): 421-444, doi:10.1080/03 066150.2016.1228629.

Pendleton W., Crush J., Nickanor N., 2014. Migrant Windhoek: Rural-Urban Migration and Food Security in Namibia. Urban Forum, 25(2): 191-205, doi:10.1007/s12132-014-9220-x.

Perch-Nielsen S.L., Bättig M.B., Imboden D., 2008. Exploring the link between climate change and migration. Climatic Change, 91(3-4): 375-393, doi:10.1007/s10584-008-9416-y.

Post R., Hudson D., Mitchell D., Bell P., Perliger A., Williams R., 2016. Rethinking the Water-Food-Climate Nexus and Conflict: An Opportunity Cost Approach. Applied Economic Perspectives and Policy, 38(4): 563-577, doi:10.1093/aepp/ppw027.

Rademacher-Schulz C., Schraven B., Mahama E.S., 2014. Time matters: Shifting seasonal migration in Northern Ghana in response to rainfall variability and food insecurity. Climate and Development, 6(1): 46-52. doi:10.1080/17565529.2013.830955.

Reis V., 2015. Sources of income of rural families and food security in Cape Verde [Fontes de rendimento das famílias rurais e a segurança alimentar em Cabo Verde]. Cadernos de Estudos Africanos, 2015(29): 129-157, doi:10.4000/cea.1808.

Sporton D., Thomas D.S.G., Morrison J., 1999. Outcomes of social and environmental change in the Kalahari of Botswana: The role of migration. Journal of Southern African Studies, 25(3): 441-459, doi:10.1080/030570799108605.

Suckall N., Fraser E., Forster P., 2017. Reduced migration under climate change: evidence from Malawi using an aspirations and capabilities framework. Climate and Development, 9(4): 298-312.

Taylor E.J., 1999. The New Economics of Labour Migration and the Role of Remittances in the Migration Process. International Migration, 37(1): 63-88, doi:10.1111/1468-2435.00066.

Tolossa D., 2010. Some realities of the urban poor and their food security situations: a case study of Berta Gibi and Gemechu Safar in the city of Addis Ababa, Ethiopia. Environment and Urbanization, 22(1): 179-198, doi:10.1177/0956247810363527.

UNHCR, n.d. Nutrition and Food Security. http:// www.unhcr.org/nutrition-and-food-security.html. Accessed 14 November 2017.

United Nations, Dept. of Economic and Social Affairs, Population Div., 2017. Trends in International Migrant Stock: The 2017 revision (United Nations database, POP/DB/MIG/Stock/Rev.2017).

Warner K., Afifi T., 2014. Where the rain falls: Evidence from 8 countries on how vulnerable households use migration to manage the risk of rainfall variability and food insecurity. Climate and Development, 6(1): 1-17, doi:10.1080/17565529.2013.8 35707 .

Warner K., Ehrhart C., de Sherbinin A., Adamo S., Chai-Onn T., 2009. In search of shelter: mapping the effects of climate change on human migration and displacement. Care International and UN University. http://www.careclimatechange.org 
Warner K., Hamza M., Oliver-Smith A., Renaud F., Julca A., 2010. Climate change, environmental degradation and migration. Natural Hazards, 55(3): 689-715, doi:10.1007/s11069-009-9419-7.

World Bank, 2018. Data Bank, World Development Indicators. http://databank.worldbank.org/ data/reports.aspx? source=world-development-indicators.
Young H., Jacobsen K., 2013. No Way Back? Adaptation and Urbanization of IDP Livelihoods in the Darfur Region of Sudan. Development and Change, 44(1): 125-145, doi:10.1111/dech.12003.

Zezza A., Carletto C., Davis B., Winters P., 2011. Assessing the impact of migration on food and nutrition security. Food Policy, 36(1): 1-6, doi:10.1016/j. foodpol.2010.11.005. 